Page 327-337. ISBN: 978-602-6 988-75-1

Web Jurnal Online: jurnal.unmuhjember.ac.id

By: Aan Anwar Sihabudina; Dini Yulianib; R. Rindu Garverac

Development of Village Based on The Eco-Village Concept Towards an Independet Village

\title{
DEVELOPMENT OF VILLAGE BASED ON THE ECO-VILLAGE CONCEPT TOWARDS AN INDEPENDET VILLAGE
}

\author{
Aan Anwar Sihabudin ${ }^{a}$, Dini Yuliani ${ }^{\mathrm{b}}$, R. Rindu Garvera ${ }^{\mathrm{c}}$ \\ ${ }^{a}$ Universitas Galuh, Ciamis, Indonesia. \\ ${ }^{b}$ Universitas Galuh, Ciamis, Indonesia. \\ ${ }^{c}$ Universitas Galuh, Ciamis, Indonesia. \\ aansihabudin55@gmail.com
}

\begin{abstract}
The purpose of this study is to improve people's understanding of managing their environment in accordance with sustainable development principles through optimizing village potential while maintaining local wisdom. With the concept of Eco-Village, the community of Sukahurip Village, Cihaurbeuti Subdistrict, Ciamis Regency is able to change people's behavior in creating a better environment, having a sense of attitude and self-reliance through community self-reliance without having to depend on government programs and feeling together the mutual cooperation that is felt has begun to fade. The research method used is descriptive qualitative research method based on documentation and interview results. The results of this study indicate that the development of a village based on the Eco-Village concept to create an independent village in Sukahurip Village has been proven by mapping the conditions of the village potential and the existence of an agroecosystem by making the Black Soldier Fly breeding center useful as a decomposer for organic waste. This study contributes to the economy of the local community in managing the social environment and sustainable productive economic enterprises whose results can increase income and family welfare without having to eliminate mutual cooperation and continue to uphold existing local wisdom through the concept of EcoVillage-based development.
\end{abstract}

Keywords: Village Development, Eco-Village Concept, Mandiri Village. 


\section{INTRODUCTION}

The potential in rural areas is so abundant, in particular, the existence of natural resources should have an impact on the conditions of better welfare of rural communities. In reality, there are still social inequalities that occur in the middle of rural communities. Likewise, over time, some villages still remain stagnant in terms of development, both infrastructure development and human resource development in rural areas. One of them, namely the occurrence of gender inequality caused by the dynamic problems of rural communities that are increasingly complex. This is in line with the opinion of Indriatmoko, Yayan. Et al. (2007: 4) which states, that gender inequality in natural resource management occurs as a result, practices: (a) subordination; (b) stereotypes; (c) impoverishment; (d) double load; and (e) violence. Subordination or nomination is an assumption that one sex is considered more important or more important. While stereotypes, namely the standard image of individuals or groups that are not in accordance with the existing empirical reality. This situation makes the village an increasingly disadvantaged area.

After the birth of policies from the Central Government that support village development, this has an impact on the condition of the community socially, culturally and economically as well as the education of rural communities. This can be seen from the infrastructure development that continues to be carried out as a development program in rural areas. Construction of development in rural areas is now becoming stronger, where rural communities participate in more progressive village development efforts. Rural communities are beginning to transform into a society that has the motivation to progress economically to enter the level of a prosperous society. In addition, there are many rural community empowerment programs to improve living standards and welfare levels.

In the midst of the rapid development efforts and the improvement of the welfare of rural communities, various problems arise in rural areas. One of the environmental problems that have an impact on rural natural conditions is damaged due to the behavior of people who are not friendly to nature. The socio-cultural and economic environment is very important for the sustainability of sustainable village development. The lower carrying capacity of the rural environment has an impact on environmental damage and poor sanitation. The situation is feared to have an impact on the declining level of public health and have a direct impact on natural conditions which will certainly be increasingly damaged.

That also happened in Sukahurip Village, Cihaurbeuti Subdistrict, Ciamis Regency which became the focus of this study. In the village, there are problems in the form of environmental sanitation caused by garbage originating from residential waste. Waste is a major problem for the village. The type of waste that is a sanitation problem in the village, namely organic and inorganic waste. Organic waste is dominated by garbage originating from settlements, such as food scraps and vegetables. Whereas inorganic waste is dominated by plastic waste. The increasing level of infrastructure development in the village is not comparable with the level of awareness of rural communities in keeping 
their environment clean. The existence of such waste certainly disrupts people's activities and if left unchecked it will make the environment dirty, and become a source of disease.

Basically, every development carried out will have an impact on usefulness but it contains risks. According to Soemarwoto, Otto (2004: 139) states, that with the development of the community in the village feels the benefits, for example, the electricity network, increasing irrigation water, and controlled floods. But there are also the adverse effects of development, namely the extinction of animals and plants, and even the eviction of residents affected by development. A solution is needed to solve the problems that arise and the complexity of the dynamics of society, especially rural communities that tend to be apathetic towards the environment.

Steps were taken by the Sukahurip Village Government, namely by drafting the Eco-Village to overcome these problems. This is done to overcome environmental problems. In addition, the Village Government involves all elements of the community in the Eco-Village program so that the program can be quickly realized. The economic aspect does not escape the attention of the Eco-Village concept. Because the concept of Eco-Village in Sukahurip Village is not only to maintain the carrying capacity of the environment to remain stable but of course the program also aims to improve the welfare of the village community. Because conservation efforts also produce economic value. The principle run by the Sukahurip Village Government is to optimize the implementation of 3R (Reuse, Reduce and Recycle) to overcome inorganic waste. Whereas to overcome the presence of organic waste is done by using natural decomposers that can produce compost, namely larvae from the Black Soldier Fly (BSF). In addition, larvae from BSF can be utilized for poultry and fish feed, as well as an alternative feed for a substitute for factory feed.

\section{VILLAGE DEVELOPMENT}

The village as the smallest part of the government system contributes to the national development effort. The accessibility of rural communities that are increasingly easy to carry out activities and access various information makes rural areas a pillar in producing goods and services. The village that had been synonymous with underdevelopment has turned into a development priority area. This is manifested by the existence of Law Number 6 of 2014 concerning Villages, in which states that villages are customary villages and villages or referred to by other names, hereinafter referred to as Villages, are legal community units that have territorial limits authorized to regulate and manage government affairs, the interests of the local community based on community initiatives, origin rights, and / or traditional rights that are recognized and respected in the system of government of the Unitary State of the Republic of Indonesia.

Based on this, the Village Government has the authority to manage the potential of its village for the benefit of community welfare. But the current challenge for the village is the emergence of the 4.0 industrial revolution. According to Santoso, Anang. D (2019: 3) states, that the Industrial Revolution 4.0 is the development of internet technology that entered the industrial world to facilitate various industrial practices. The Industrial Revolution 4.0 was marked by the widespread use of the internet, with increasingly small, 
strong and inexpensive sensors and the use of artificial intelligence and machine learning. The development of artificial intelligence is very fast, driven by the increasing sophistication of computer technology and the availability of various types of data with algorithms that can predict the interests of every internet user. This certainly can be the basis of the direction of development of the village itself to be more adaptive to developments, and changes in the times.

Village development rests on the potential that exists in the village itself, both the potential of natural resources and human resources in the village. village development currently focuses a lot on developing villages into rural areas where people have sufficient environmental insights. Management of village potential, especially natural potential in rural areas, is needed to explore and use it wisely. This is done so that the environment can be maintained.

The participation of the community, business people, religious leaders, academics, non-governmental organizations, and government officials in developing environmentally sound villages is the key to controlling environmental damage (Nedi Sunaedi \& Ruli As'ari, 2018). The role of various parties will be very helpful in accelerating and maintaining an environment that is maintained. Exploration that is without planning and only oriented to the benefits obtained will have a negative impact on environmental conditions. Well-maintained environmental conditions will make village development more focused and sustainable.

There are several strategies and implementations carried out by the Village Government in order to realize better village development. One of the steps taken, namely by making the village a tourist spot and this is known as a tourist village. Essentially a tourism village is the development of a village by utilizing the capabilities of elements in the community and villages that function as tourist product attributes into a series of integrated tourism activities and have a specific theme according to the characteristics of the village (Eko. M, 2011). Likewise with the Sukahurip Village which offers a typical rural panorama. This is because the location of Sukahurip Village is located under the foot of Mount Syawal. Environmental conditions that represent mountainous areas make Sukahurip Village very suitable to be an environment-based Tourism Village.

Environmental development in the village is expected to make equitable development in rural areas better and balanced with the preservation of the environment. Public awareness of the importance of environmental carrying capacity is carried out by means of conservation that educates of course. Villagers who understand the benefits of a protected environment and understand how to manage the environment well will have an impact on the level of community awareness of the environment. However, with the condition of disadvantaged rural communities, wise steps are needed to regulate the community in exploring village potential. Active and active communities to promote the environment in rural areas contribute to maintaining the authenticity of natural resources in rural areas.

Based on this, the main key in village development lies in community participation. The level of community participation can be measured by 3 (three) approaches, namely: (a) the dimension of thought; (b) power dimension; and (c) material dimensions (Eko. M. 
2011). In the dimension of thinking, community participation takes the form of constructive ideas, ideas, and opinions in the village development effort. These ideas and ideas must be causal and correlate with the progress of rural areas, and certainly can be measured. Dimensions of energy in the form of community slimming in physical form in building a place or providing supporting facilities in the village development effort. While the material dimensions are in the form of funds originating from the community and are used to assist village development, and in fundraising it is voluntary.

In village development, village innovation is also needed to provide stimulants in creating competitive villages. Village progress and improvement in people's living standards in this innovation village involved all elements of the village on 4 (four) pillars, namely: (a) Public Services, basic administrative, educational and health services; (b) Agriculture, plantations, livestock, fisheries become integrated sectors with a touch of science and technology; (c) Micro and Small and Medium Enterprises in accordance with village potential and; (d) Facilities and infrastructure, development by utilizing various programs in an integrated manner (Rahadi, D.R, 2016). Community involvement remains the main thing for a more advanced, adaptive village development process. Public service as part of the most basic service to meet administrative needs for rural communities is the most important thing in the implementation of Village Government. The field of education and health is also a priority in improving the quality of human resources in rural areas, and it aims to increase the immunity of rural communities to various types of diseases and the fulfillment of nutritional needs can increase the Human Development Index at the village level.

Infrastructure development and development of village economic potential can encourage the acceleration of rural development. Accessibility of villages is needed to reach out and support in terms of improving the welfare of rural communities. A new era for village development is naturally focused on the level of welfare of rural communities. The abundant potential of resources is the main capital for improving the welfare of rural communities through the development of the village itself.

\section{THE ECO-VILLAGE CONCEPT OF SUKAHURIP VILLAGE}

The Eco-village program Sukahurip Village is oriented towards solving the problem of waste, sanitation and the environment, especially the state of the forest which causes some natural disasters to occur. Based on the results of interviews in 1995 there were landslides and flash floods which resulted in the destruction of agricultural land and livestock up to around 5 ha, as well as the closure of many springs which became one of the sources of community needs. Some sources of springs dry up, one of which was the Cihaniwung spring which could not function again. Then Sukahurip Village which has the dream of becoming a tourist village is still constrained by the problem of garbage, both organic and inorganic waste. This is one of the obstacles to the formation of tourism villages that are environmentally sound.

This is in line with the opinion of Deni W.S (2013), stating that a village system development can increase natural resources so that villagers can become prosperous. So that the villagers who urbanize into the city are reduced. Village system development 
uses the Eco-village concept, namely a concept of village development that pays attention to the environment and minimizes environmental damage. Development of the village system includes the use of water resources using environmentally friendly modern technology, the use of agricultural land using modern technology that is environmentally friendly, building research centers, educational facilities, social culture, and structuring land use.

Likewise, the Eco-village concept in Sukahurip Village remains focused on reducing and utilizing organic waste, and inorganic to have economic value. Organic waste is made into compost and is used to fertilize the soil. Every house in the Sukahurip Village area is fostered to be more productive, one of which is food independence for the household. The efforts are made, namely by planting productive crops, such as horticulture plants. In addition, the inorganic waste itself is recycled into objects of economic value, such as plastic baskets, mats, and even ornaments.

With the existence of an environmentally friendly village concept, it is hoped that the program can increase public awareness of the environment. Community productivity through guidance programs and even assistance provided by the Village Government is expected to make the economy of the Sukahurip Village more prosperous. Natural damage caused by people's behavior that is not friendly to nature can be reduced and immediately renewed. The mindset of the community is also a concern for the EcoVillage concept in Sukahurip Village. This means that the mindset of the Sukahurip Village community is invited to be wise in utilizing nature to be wiser.

Besides that, through a waste bank that is part of the Eco-Village program, it can make people aware not to dispose of trash carelessly, but it is used for things that have more economic value. With this program, the environmental damage that has occurred can be restored and the community can take advantage of the natural potential in the countryside well. The principle of effectiveness and efficiency in implementing the EcoVillage program and with the involvement of the community produced satisfactory results for the implementation of the program. In addition, the existence of economic values contained in the program can be an attraction for rural communities to change more powerfully. The productivity of rural communities is very necessary for the welfare and improvement of living standards. Community involvement in this program, which aims to improve the local economy and the welfare of the village. Nevertheless, the Village Government must be adaptive to social dynamics, to prevent the occurrence of polemic in the community.

\section{RESULTS AND DISCUSSION}

Based on the results of a study conducted by Sukahurip Village, Cihaurbeuti Subdistrict, it has been quite successful in overcoming environmental problems and creating new economic potential through the Ecovillage program. The program has changed the paradigm of society, where waste can be a potential economic value for rural communities. This can encourage the economy of the community and increase village independence in an effort to improve the welfare of the village community. The reduction in underprivileged groups is the main objective of the Ecovillage program. 
Development of Village Based on The Eco-Village Concept Towards an Independet

The solution initiated by the Sukahurip Village Government was the Ecovillage program. There are several innovative steps in the realization of the Ecovillage program, as follows:

a.Awareness Action Plan

1) Dissemination of village level Ecovillage action plans by mobilizing support and commitment from leaders;

2) Dissemination and synchronization of the Ecovillage action plan with crosssector or cross-district activities;

3) Mass garbage collection movement;

4) Dissemination of trash from home;

5) Surgical regulation or legislation relating to waste;

6) Movement for love cleanliness in the Taklim Assembly and School;

7) Socialization of the fatwa of the Indonesian Ulema Council (MUI) regarding waste and the environment;

8) Preparation of legal umbrella or regulation of village products;

9) Establishment and development of waste banks;

10) Making banners or warning signs for love-hygiene movements; and

11) Action movement to make murals or graphs with the theme of love for the environment.

b. Organic Waste Processing

1) Training and action movements make Complete Micro-Organisms (MOL);

2) Training and action movements to make compost with Takakura methods and jars and various other composting methods;

3) Training and action movements for maggot and worm cultivation; and

4) Training and action movements for making alternative feed made from garbage.

c.Processing of Non-Organic Waste

1) Training and action movements to make and use eco bricks;

2) Training and action movement for recycling plastic waste;

3) Training and action movements for recycling paper waste;

4) Training and action movements for recycling metal waste; and

5) Training and action movements for recycling glass or glass waste.

d. Spatial Planning

1) Movement of nursery for garden plants and medicinal plants;

2) The movement to make planting media by utilizing garbage and processed waste products;

3) Action on the development of Sustainable Food House Area;

4) Vertical garden action;

5) Action movements make hydroponics; and

6) Organic gardening care plant movements.

e.Development

1) Art and cultural degree and environmental-themed creative performances; 
Page 327-337. ISBN: 978-602-6 988-75-1

Web Jurnal Online: jurnal.unmuhjember.ac.id

By: Aan Anwar Sihabudina; Dini Yulianib; R. Rindu Garverac

Development of Village Based on The Eco-Village Concept Towards an Independet Village

2) Exhibition of waste management works; and

3) Product marketing training resulting from waste management creativity.

f. Program and Supporting Activities

1) Solid Waste Infrastructure;

2) Assistance with waste bank equipment (scales, sacks, etc.);

3) Procurement of trash cans;

4) Procurement of biodigesters;

5) Procurement of garbage carts;

6) Procurement of motorized vehicles transporting waste;

7) Procurement of waste counting machines;

8) Making garbage collection tanks; and

9) Making integrated waste processing houses.

g. Supporting Infrastructure

1) Construction of WWTP and Communal Septic Tanks;

2) Procurement of biogas installations; and

3) Help with seeds or seeds and trees.

h. Collaborative Activities

1) KB Village;

2) The movement to Plant a Million Trees;

3) Community Based Total Sanitation Program (STBM) and Multifunctional Village;

4) Climate Village Program; and

5) Utilization of Village Funds for Environmental Improvement and Conservation.

In addition, there are 5 (five) ways carried out by the Government of Sukahurip Village, District of Cihaurbeuti, Ciamis Regency, as follows:

a. Society as a Subject

In implementing the Ecovillage program the village community is positioned as the main subject or actor in the management and development of Ecovillage. Community involvement in the Ecovillage program is expected to be able to build community values, such as mutual cooperation, cooperation, and responsibility in the effort to achieve the goals of the community group itself. In addition, in rural communities, the principles of democracy have been built and this has become a basic foundation in community life and deliberation in solving problems.

b. Cooperation between Government Institutions

Ecovillage management is a shared responsibility in terms of the technical development and sustainability of the program. Cooperation between Government Institutions is intended to accelerate the realization of development. The village's potential is dominated by natural resources, so agricultural land is the prima donna of the village community to earn income. So it is necessary to provide assistance for the welfare of the people who work as farmers. The agricultural and plantation assistance model is the right model to support the Ecovillage program

c. Respect for Cultural Values 
Respect for cultural values in the Ecovillage program is intended to help maintain natural conservation. The methods used for conservation areas are carried out by watershed-based approaches or based on the condition of the variety of ecosystems, habitats, distribution of wild plants and animals, and this cannot be separated from considering changes in land use due to development and resulting from dependence on village resources forest power and waters.

d. Role of Leadership

In managing the Ecovillage area is supported by the leadership capabilities of a Village Head. Strong leadership can build multi-stakeholder collaboration or collaboration by adhering to the principles of mutual respect, mutual trust, and mutual benefits. Cooperation or partnership is a necessity in the management of the Ecovillage area.

\section{e. Decision-making}

Proper decision making will produce sustainable benefits in every policy produced. Policies that fully support the interests of the community will have an impact on improving people's welfare. Similarly, the Ecovillage area determination must be considered about its effects or effects.

Based on this, the Ecovillage concept in Sukahurip Village is community-based and does not heed the cultural values that develop in the community to preserve conservation and environmental sustainability. The problem of waste, both organic and inorganic waste has been overcome by the existence of a Waste Bank even though it has not been maximally maximized in overcoming the problem. The geographical conditions in the village that support agricultural activities make the area included in fertile rural areas. An ecovillage is expected to be one of the leading programs in solving welfare problems in rural areas.

\section{METHODOLOGY}

The research method used in this study is a qualitative descriptive method. According to Jane Richie (in Moleong. Lexy. J, 2011: 6) states, that qualitative research is an attempt to present the social world, and its perspective in the world, in terms of concepts, behaviors, perceptions, and problems about the human being studied. The use of qualitative descriptive methods in this study is to explain and describe the phenomena related to the analysis of ecovillage-based village economic independence in Sukahurip Village, Cihaurbeuti District, Ciamis Regency. 
Page 327-337. ISBN: 978-602-6 988-75-1

Web Jurnal Online: jurnal.unmuhjember.ac.id

By: Aan Anwar Sihabudina; Dini Yulianib; R. Rindu Garverac

Development of Village Based on The Eco-Village Concept Towards an Independet

Village

\section{CONCLUSION}

Based on the results of research that has been carried out related to the Ecovillage program. it can be concluded, that:

An innovative step in the realization of the Ecovillage program, which is carried out by stages: (1) Awareness action plans; (2) Processing of organic waste; (3) Processing of inorganic waste; (4) Spatial planning; (5) Development; (6) Programs and supporting activities; (7) Supporting infrastructure; and (8) Collaborative Activities.

Application of the existing governance principles in Sukahurip Village, namely: (1) participation; (2) Openness; (3) Responsibility; and (4) Accountability.

The Ecovillage program in Sukahurip Village still has to be developed and when the program is realized properly, it can be developed into a conservation area with the concept of ecotourism. The level of economic independence of Sukahurip Village, Cihaurbeuti District, Ciamis Regency is independent. The ecovillage program in Sukahurip Village, Cihaurbeuti Subdistrict, Ciamis Regency is effective in increasing village independence in economic terms. 
Page 327-337. ISBN: 978-602-6 988-75-1

Web Jurnal Online: jurnal.unmuhjember.ac.id

By: Aan Anwar Sihabudina; Dini Yulianib; R. Rindu Garverac

Development of Village Based on The Eco-Village Concept Towards an Independet Village

\section{References}

Deni W.S (2013). Desa Mandiri Berbasis Ecovillage. Undergraduate thesis, Universitas Diponegoro.

Eko. M. 2011. Partisipasi Masyarakat dalam Pengembangan Desa Wisata Karanggeneng, Purwobinangun, Pakem, Sleman. SEPA.7.(2).91-101.

Moleong. Lexy. J. 2011. Metodologi Penelitian Kualitatif Edisi Revisi. Bandung: PT. Remaja Rosdakarya.

Indriatmoko, Yayan. Dkk. 2007. Dari Desa ke Desa: Dinamika Gender dan Pengelolaan Kekayaan Alam. Jakarta: CIFOR.

Nedi Sunaedi \&Ruli As'ari. 2018. Program Ecovillage Sebagai Upayaperubahan Perilaku Masyarakat Dalam Pelestarian Kawasan Das Citanduy Di Kecamatan Panumbangan Kabupaten Ciamis. Prosiding Seminar Nasional Geografi UMS IX 2018.

Rahadi, D.R. 2016. Model Pengembangan Kampung sebagai Desa Inovatif (Studi Kasus Kota Palembang). Firm Journal of Management Studies.1.(2).

Santoso, Anang. D. 2019. Desa Cerdas: Transformasi Kebijakan dan Pembangunan Desa Merespon Era Revolusi Industri 4.0. Yogyakarta: UGM.

Soemarwoto, Otto. 2004. Ekologi Lingkungan Hidup dan Pembangunan. Jakarta: Djambatan, 